JPPIPA, Vol. 1 No. 22016
Jurnal Penelitian Pendidikan IPA
http://journal.unesa.ac.id/index.php/jppipa

\title{
MODEL PEMBELAJARAN LEARNING CYCLE 5E: MENGAKTIFKAN SISWA PADA MATERI SUHU DAN PERUBAHANNYA
}

Oleh:

Dyah Astriani ${ }^{1}$, Nurun Nisa'ul Istiqomah ${ }^{2}$

${ }^{1}$ Jurusan IPA, FMIPA, Universitas Negeri Surabaya

${ }^{2}$ SMP Al-Muslim

\begin{abstract}
Abstrak
Penelitian ini bertujuan untuk mendeskripsikan aktivitas siswa terhadap implementasi model Learning Cycle 5E pada materi suhu dan perubahannya di kelas VII SMP Negeri 1 Sidoarjo. Jenis penelitian ini adalah deskriptif kuantitatif. Sampel penelitian adalah siswa kelas VII-6. Teknik pengumpulan data adalah dengan pengamatan pada aktivitas siswa pada saat pembelajaran. Metode analisis data aktivitas siswa dengan menggunakan skor rata-rata persentase. Hasil penelitian menunjukkan aktivitas siswa yang dominan adalah melakukan diskusi antar siswa sesuai dengan materi pembelajaran yang sedang berlangsung $(23,78 \%)$. Aktivitas siswa yang jarang muncul adalah siswa mengamati gambar, video atau demonstrasi yang dilakukan oleh guru $(8,53 \%)$.
\end{abstract}

Kata Kunci: Learning cycle, aktivitas siswa.

\section{Abstract}

This study aimed to describe the students' activity on the implementation of the model Learning Cycle 5E on the topic of temperature and its changes in grade 7 of SMP Negeri 1 Sidoarjo. This research method was quantitative descriptive. The samples were students of Grade 7 Class B. The data colected by observe the students' acitivities during the class. Methods of data analysis student activity by using the average score percentage. The results showed that the dominant student activitiy is a discussion between students in accordance with the ongoing learning materials $(23.78 \%)$. The student activity that rarely showed in the class is students observe a picture, a video or a demonstration doing by teachers $(8.53 \%)$.

Keywords: Learning Cycle, student activity.

(C) 2016 Universitas Negeri Surabaya

\begin{tabular}{lr}
\hline${ }^{1}$ Alamat Korespondensi: & p-ISSN: 2527-7537 \\
Jurusan IPA FMIPA Universitas Negeri Surabaya & e-ISSN: 2549-2209 \\
Surabaya, Indonesia & \\
Email: dyahastriani@ @unesa.ac.id &
\end{tabular}




\section{PENDAHULUAN}

Kurikulum adalah seperangkat rencana dan pengaturan mengenai tujuan, isi, dan bahan pelajaran serta cara yang digunakan sebagai pedoman penyelenggaraan kegiatan pembelajaran untuk mencapai tujuan pendidikan tertentu (UU nomor 20 tahun 2003; PP nomor 19 tahun 2005). Berdasarkan Permendikbud nomor 58 tahun 2014, kurikulum Sekolah Menengah Pertama/ Madrasah Tsanawiyah sekarang adalah Kurikulum 2013. Tema pengembangan Kurikulum 2013 adalah kurikulum yang dapat menghasilkan insan Indonesia yang produktif, kreatif, inovatif, afektif melalui penguatan sikap, keterampilan dan pengetahuan yang terintegrasi (Lampiran III, Permendikbud nomor 58 tahun 2014).

Salah satu mata pelajaran yang diharapkan dapat menerapkan pembelajaran Kurikulum 2013 adalah Ilmu Pengetahuan Alam (IPA). Pembelajaran IPA di SMP pada Kurikulum 2013 dikembangkan sebagai konsep pembelajaran IPA terpadu (integrated science). IPA merupakan pengetahuan ilmiah yang telah mengalami uji kebenaran melalui keterampilan proses sains dan metode ilmiah dengan ciri objektif, metodik, sistematis dan universal (Toharudin, dkk., 2011).

Harapan tidak selalu berjalan sesuai dengan kenyataan, sehingga menimbulkan masalah dalam pembelajaran. Berdasarkan observasi di SMP Negeri 1 Sidoarjo menunjukkan bahwa pada lembar kerja siswa (LKS) yang digunakan oleh siswa tidak terdapat kegiatan yang menunjang keterampilan proses seperti merumuskan masalah, merumuskan hipotesis dan mengidentifikasi variabel. Berdasarkan hasil angket pra-penelitian, dari 30 responden kelas VII sebanyak 62,07\% menyatakan bahwa IPA merupakan pelajaran sulit. Hal ini dikarenakan materi IPA, salah satunya materi suhu dan perubahannya, lebih banyak menghafal dan membutuhkan pemahaman yang lebih. Sebanyak 51,72\% responden mengalami kesulitan dalam merumuskan masalah sehingga guru harus memberikan bimbingan dalam pembelajaran. Siswa juga mengalami kesulitan dalam menganalisis hasil pengamatan atau eksperimen. Hal ini juga diperkuat dengan hasil angket yaitu 58,62\% responden yang mampu menganalisis dalam kegiatan pengamatan atau eksperimen. Sebanyak $55,17 \%$ responden yang mampu mengkomunikasikan hasil diskusi kelompok. Hal ini berpengaruh pada keterampilan proses sains siswa, sehingga perlu dilatihkan keterampilan-keterampilan untuk mewujudkan siswa aktif melalui penerapan model pembelajaran.

Karakteristik materi suhu dan perubahannya menunjukkan bahwa materi ini membutuhkan suatu keterampilan proses sains dalam memahaminya. Sebagai contoh, dalam mempelajari tentang peristiwa pengukuran suhu dan pemuaian yang disebabkan oleh perubahan suhu, siswa akan lebih memamahi jika mengontruksi sendiri pemahamannya melalui kegiatan penyelidikan ilmiah. Penyelidikan ilmiah tersebut dengan menggunakan keterampilan proses sains yaitu mengamati, merumuskan masalah, merumuskan hipotesis, mengidentifikasi variabel, melakukan eksperimen, menganalis, menyimpulkan, dan mengkomunikasikan. Dengan kegiatan penyelidikan ini diharapkan keterampilan bernalar siswa meningkat dan tidak terjadi miskonsepsi.

Model pembelajaran yang inovatif diperlukan oleh siswa sehingga siswa dapat aktif, menerima materi IPA dengan mudah, menguasai pengetahuan serta kompetensi yang harus dicapai serta mengembangkan keterampilan proses sains. Salah satunya yaitu dengan model pembelajaran Learning Cycle 5E yang terdiri dari beberapa fase yaitu engagement, exploration, explanation, elaboration, dan evaluation (Bybee, 2009). Model pembelajaran Learning Cycle merupakan model pembelajaran dengan rangkaian tahapan yang disusun secara terorganisir sehingga siswa dapat menguasai kompetensi-kompetensi yang harus dicapai dengan cara berperan aktif dalam pembelajaran (Fajaroh dan Dasna, 2007). Model ini memiliki tujuan yaitu mengembangkan konsep-konsep dan keterampilan bernalar melalui kegiatan penyelidikan ilmiah (Dahar, 2011). Model pembelajaran Learning Cycle $5 E$ memiliki fase-fase yang dapat diorientasikan pada Kurikulum 2013 sehingga dapat melatihkan keterampilan proses sains pada siswa. Siswa dapat berperan aktif dan termotivasi dalam mengembangkan keterampilan dalam menggunakan pola-pola penalaran umum yang terlibat dalam penyusunan hipotesis dan pengujiannya.

Handayani, dkk (2013) penerapan model Learning Cycle $5 E$ dapat meningkatkan aktivitas belajar siswa kelas VIII dengan bantuan authentic assesment. Oktaria, dkk (2015) dengan menerapkan Learning Cycle $5 E$ aktivitas belajar siswa meningkat dalam semua aspek, yaitu mengumpulkan data/informasi, mengungkapkan ide/pendapat, mempresentasikan hasil pengamatan/diskusi, dan membuat kesimpulan. Penelitian dengan model siklus belajar telah membuat siswa aktif dalam belajar yaitu dengan kriteria aktif dan sangat aktif (Wulandari dkk., 2013)

Berdasarkan uraian di atas maka dilakukan penelitian dengan menerapkan Learning Cycle $5 E$ untuk mengaktifkan siswa kelas VII pada pembelajaran materi Suhu dan Perubahannya 
didukung LKS berorientasi inkuiri yang didalamnya terdapat beberapa komponen seperti merumuskan masalah, hipotesis, variabel, dan membuat kesimpulan

\section{METODE}

Jenis penelitian yang dilakukan dalam penelitian ini adalah deskriptif kuantitatif yang mendeskripsikan aktivitas siswa kelas VII-6 SMP Negeri 1 Sidoarjo pada semester genap tahun ajaran 2014-2015 dengan jumlah 30 siswa yang terdiri dari 15 siswa perempuan dan 15 siswa lakilaki

Metode yang digunakan untuk memperoleh data yaitu observasi aktivitas siswa yang dilakukan saat kegiatan pembelajaran dengan Learning Cycle 5E mengacu pada lembar pengamatan aktivitas siswa (instrumen II). Data yang diperoleh merupakan frekuensi aktivitas pada tiap aspek pengamatan. Analisis data menggunakan persentase yaitu frekuensi aktivitas pada setiap aspek pengamatan yang sering muncul dibagi dengan banyaknya frekuensi jumlah total semua aspek pengamatan dikali $100 \%$.

\section{HASIL DAN PEMBAHASAN}

Data persentase aktivitas siswa pada pertemuan I sampai III dapat dilihat pada gambar 1 sebagai berikut.

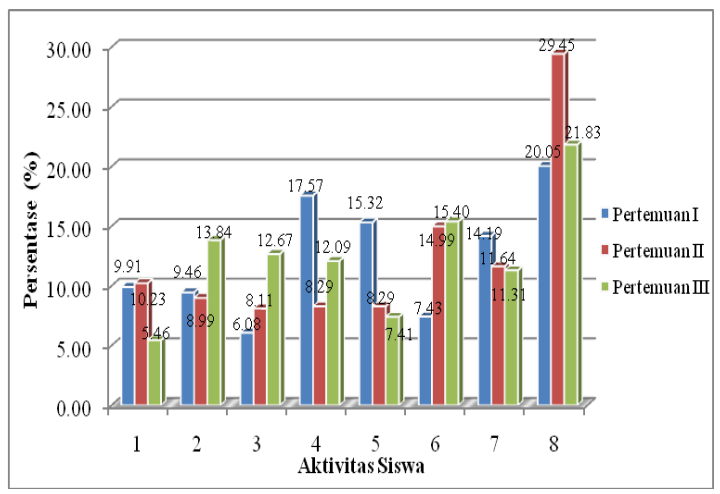

Gambar 1. Grafik Aktivitas Siswa pada Pertemuan I, II dan III

Keterangan Aktivitas:

1. Mengamati gambar, video atau demonstrasi yang dilakukan oleh guru.

2. Membuat rumusan masalah pada kegiatan yang dilakukan secara berkelompok.

3. Membuat hipotesis pada kegiatan yang dilakukan secara berkelompok.

4. Mengidentifikasi variabel pada kegiatan yang dilakukan secara berkelompok.

5. Menyimpulkan hasil data yang telah diperoleh secara berkelompok.
6. Mengkomunikasikan hasil data yang telah didiskusikan berkelompok secara runtut dan jelas.

7. Melakukan tanya jawab dan/ atau berpendapat baik dengan guru dan/ atau siswa lainnya sesuai dengan materi pembelajaran yang sedang berlangsung.

8. Melakukan diskusi antar siswa sesuai dengan materi pembelajaran yang sedang berlangsung.

Aktivitas siswa yang dominan pada pertemuan I sampai III adalah siswa melakukan diskusi antar siswa sesuai dengan materi pembelajaran yang sedang berlangsung $(23,78 \%)$. Aktivitas siswa siswa yang ditunjang dengan LKS berorientasi inkuiri dapat melibatkan siswa secara aktif dalam pembelajaran, salah satunya melalui kegiatan diskusi (Astriani, 2006). Siswa melakukan kegiatan diskusi dengan siswa lain mulai dari fase engagement sampai evaluation. Oleh sebab itu, siswa selalu aktif dalam pembelajaran dengan model Learning Cycle $5 E$ dan menjadikan pembelajaran tersebut berpusat pada siswa. Hal tersebut sesuai dengan pernyatan dari Nur dan Wikandari (2011) bahwa siswa yang aktif menjadikan pembelajaran terpusat pada siswa (student-centered instruction). Keterlibatan siswa secara aktif juga menjadikan pembelajaran menjadi efektif sehingga siswa menjadi pusat kegiatan pembelajaran serta pembentukan kompetensi (Kosasih, 2014).

Kegiatan diskusi ini bertujuan untuk melatih siswa dalam mengemukakan pendapatnya. Pendapat tersebut butuh didiskusikan dan diuji. Siswa akan belajar dengan berdiskusi dan merefleksi apakah pendapatnya akan berguna atau tidak. Siswa akan mengevaluasi apabila pendapatnya cocok dan sesuai dengan kenyataan maka akan dikonstruk dalam memorinya. Kegiatan ini merupakan sikap ilmiah yang butuh dikembangkan (Dahar, 2011). Siswa perlu dilatih keterampilan analisis yang menunjang pengembangan pengetahuan dan inovasi untuk dirinya sendiri (Areesophonpichet, 2013).

Aktivitas siswa yang jarang muncul pada pertemuan I sampai III adalah siswa mengamati gambar, video atau demonstrasi yang dilakukan oleh guru $(8,53 \%)$. Faktor yang menyebabkan adalah kegiatan pengamatan hanya muncul pada beberapa fase (tahapan) saja, siswa kurang antusias dalam pengamatan dan penentuan aspekaspek pada pengamatan yang kurang jelas dari guru. Hal ini sesuai dengan pernyataan Kosasih (2014) bahwa kegiatan pengamatan akan berlangsung dengan baik apabila didasari dengan tujuan yang jelas dan penentuan aspek-aspek apa saja yang harus diamati. Keterampilan mengamati perlu dilatihkan kepada siswa karena 
merupakan keterampilan proses sains dasar yang penting dalam mengembangkan dan melakukan keterampilan proses berikutnya (Toharudin, dkk., 2011). Hal penting yang harus diperhatikan guru untuk meningkatkan aktivitas siswa adalah perlunya kerangka konseptual untuk membantu siswa memilih kegiatan belajar dalam rangka meningkatkan pemahaman (Hanuschin \& Michele, 2008)

\section{PENUTUP}

Aktivitas siswa yang dominan pada implementasi model Learning Cycle 5E materi suhu dan perubahannya untuk pertemuan I sampai III adalah siswa melakukan diskusi antar siswa sesuai dengan materi pembelajaran yang sedang berlangsung (23,78\%). Aktivitas siswa yang jarang muncul adalah siswa mengamati gambar, video atau demonstrasi yang dilakukan oleh guru $(8,53 \%)$.

Pembelajaran dengan menggunakan Learning Cycle dapat mengaktifkan siswa dalam belajar, namun perlu dirancang agar seluruh aktivitas siswa dapat optimal pada semua komponen, misalnya dengan melakukan pendampingan oleh guru maupun tutor sebaya selama proses pembelajaran

\section{DAFTAR PUSTAKA}

Areesophonpichet, Sornnate. $2013 . \quad$ A Development of Analytical Thinking Skills of Graduate Students by using Concept Mapping. The Asian Conference on Education Official Conference Proceedings 2013 Diakses melalui http://iafor. org/archives/offprints/ace2013offprints/ACE2013_0381. pdf

Astriani, D. 2006. Implementasi Perangkat Pembelajaran Biologi Dengan Setting Metode Inkuiri Dalam Setting Pembelajaran Kooperatif di Madrasah Aliyah Negeri Surabay. Tesis Magister, Universitas Negeri Surabaya.

Bybee, Rodger W. 2009. The BSCS 5E Instructional Model and $21^{\text {st }}$ Century Skills, (Online), (http:// itsisu. concord. org/share/

Bybee_21 ${ }^{\text {st }}$ Century_Paper.pdf, diakses 10 Desember 2014).

Dahar, R. W. 2011. Teori-teori Belajar\& Pembelajaran. Jakarta: Erlangga.

Fajaroh, F dan Dasna, I. W. 2007. Pembelajaran dengan Model Siklus Belajar (Learning Cycle). Jurusan Kimia FMIPA UM, (Online), (http://lubisgrafura. wordpress. com/2007/09/20/pembelajaran-dengan- model-siklus-belajar-learning-cycle/, diakses 10 Desember 2104).

Handayani, R.D., Prianto, A., Prihandono, T. 2013. Penerapan Model Learning Cycle 5E dengan Authentic Assessment untuk Meningkatkan Aktivitas dan Hasil Belajar IPA Fisika Siswa Kelas VIII B SMPN 2 Jangkar Situbondo Tahun ajaran 2012/2013. Jurnal Pendidikan Fisika 2(3): hal $336-340$.

Hanuschin, D. L., \& Michele H. L. 2008. Using the Learning Cycle as a Model for Teaching the Learning Cycle to Preservice Elementary Teachers. Journal of Elementary Science Education 20(2): 51-66.

Kosasih, E. 2014. Strategi Belajar dan Pembelajaran: Implementasi Kurikulum 2013. Bandung: Yrama Widya.

Nur, M dan Wikandari, P.R. 2011. Pengajaran Berpusat kepada Siswa dan Pendekatan Kontruktivis dalam Pengajaran: Edisi 5. Surabaya: Universitas Negeri Surabaya Pusat Sains dan Matematika Sekolah (PSMS).

Oktaria, D., Sikumbang, D., Achmad, A. 2015. Penerapan Model Pembelajaran Learning Cycle 5E Terhadap Aktivitas Belajar dan Penguasaan Konsep. Jurnal Bioterdidik 2(10): Diakses melalui http://download. portalgaruda. org/article.

php article $=288505 \&$ val $=7233 \&$ title $=$ PE NERAPAN\%20MODEL\%20PEMBELA JARAN\%20LEARNING\%20CYCLE\%2 05E\%20TERHADAP\%20AKTIVITAS\% 20BELAJAR\%20DAN\%20PENGUASA AN\%20KONSEP

Peraturan Menteri Pendidikan Dan Kebudayaan Nomor 103 Tahun 2014 tentang Pembelajaran pada Pendidikan Dasar dan Pendidikan Menengah.

Peraturan Menteri Pendidikan Dan Kebudayaan Nomor 104 Tahun 2014 tentang Hasil Belajar oleh Pendidik pada Pendidikan Dasar dan Pendidikan Menengah.

Peraturan Menteri Pendidikan Dan Kebudayaan Nomor 19 Tahun 2005 tentang Standar Nasional Pendidikan.

Peraturan Menteri Pendidikan Dan Kebudayaan Nomor 58 Tahun 2014 tentang Kurikulum 2013 Sekolah Menengah Pertama/ Madrasah Tsanawiyah.

Toharudin, U dan Hendrawati, S. 2011. Membangun Literasi Sains Peserta Didik. Bandung: Humaniora. 
Undang-Undang Republik Indonesia Nomor 20 Tahun 2003 tentang Sistem Pendidikan Nasional.

Wulandari, B., Kartijono, N.E., HB.F. Putut M.

2013. Penerapan Pembelajaran Model
Siklus Belajar Pada Materi Jamur di SMA. Unnes Journal of Biology Education 2(3): 313-320 